\author{
E. Dudinova (iD), S. Talgat \\ Al-Farabi Kazakh National University, Kazakhstan, Almaty, \\ e-mail: Elena.Dudinova@mail.ru; \\ e-mail: talgatsholpan@mail.ru
}

\title{
ENVIRONMENTAL DISCOURSE IN THE SOCIAL NETWORKS OF KAZAKHSTAN: THE CONSTRUCTION OF AN IMPERATIVE
}

Constructive changes in the media landscape due to the intensification of social networks launch new modules of social discourse. Nowadays environmental theme getting particular interest, the popularity of which is related to a number of factors, including the growth of environmental awareness caused by open access to information on social networks. This includes developing literacy in environmental management and environmental conservation, as well as quick notification of environmental incidents.

The purpose of the study is to analyze the impact of the environmental content of social networks on the construction of the environmental imperative in the minds of young people in Kazakhstan. In this regard, the most popular social networks were studied, audience segmentation by age and level of education was performed, and also authors analyzed social media content in the ecology field. Using the methods of comparison, review, content analysis and survey, the authors identified the most sustainable signs of constructing environmental awareness of the youth audience in social networks.

The authors came to the conclusion that nowadays the tendency of including environmental topics in the array of the concept of sustainable development is becoming more and more persistent in the minds of young Kazakhstanis, and as a result, there are forming a number of factors of low tolerance for imbalance in this area, including politics and economy. The authors also note an increase of interest in the categories of social responsibility and ethics, which leads to a conscious understanding of universal values, the rule of law, social activity and the desire for social integration. At a higher level of development of environmental awareness, the young generation of Kazakhstanis is able to form economic and political discourse, as well as accumulate a mental appeal to the state on the issue of balance and coherence in various fields.

The presented study involves the integration of several areas at once, which makes its results interesting for understanding the variability of modern forms of environmental discourse, the specifics of changes in audience's behavior, its transformation into an active direction, audience agent which is capable to generate its own content and media communication, excluding traditional media.

Key words: ecology, social networks, youth, environmental awareness, sustainable development, audience.

\section{Е. Аудинова, Ш. Талгат}

Ә^-Фараби атындағы Қазақ ұлттық университеті, Қазақстан, Амматы қ., e-mail: Elena.Dudinova@mail.ru;

e-mail: talgatsholpan@mail.ru

\section{Қазақстанның әлеуметтік желілеріндегі экологиялық дискурс: императивтің құрылысы}

Әлеуметтік желілерді күшейту арқылы медиа ландшафтттағы сындарлы өзгерістер әлеуметтік Аискурстың жаңа модульдерін іске қосуда. Бүгінгі таңда экологиялық тақырып ерекше қызығушылық тудырады, оның танымалдылығы бірқатар факторларға байланысты, оның ішінде әлеуметтік желілердегі ақпаратқа қол жетімділіктің арқасында экологиялық сананың өсуі. Бұған экологиялық менеджмент және қоршаған ортаны қорғау саласындағы сауаттылықты арттыру, сонымен қатар экологиямық инциденттер туралы тез араАа хабарлау мүмкіндігі кіреді.

Зерттеу мақсаты - әлеуметтік желілердегі экологиялық мазмұнның Қазақстандағы жастардың санасында экологиялық императивтің құрылысына әсерін талдау. Осыған байланысты ең танымал әлеуметтік желілер зерттелді, аудитория жас шамасы мен білім деңгейі бойынша бөлінді, экология саласындағы әлеуметтік желілердің мазмұны талданды. Салыстыру, шолу, мазмұнды талдау және сауалнама әдістерін қолдана отырып, авторлар әлеуметтік желілердегі жастар аудиториясының экологиялық білімдерін қалыптастырудың ең тұрақты белгілерін анықтады.

Авторлар бүгінде жас қазақстандықтардың санасында экологиялық тақырыптардың тұрақты Ааму тұжырымдамасының құрамына ену тенденциясы барған сайын күшейе түсуде Аеген нәтижеге 
жетіп, оның ішінде саясат пен экономикадағы теңгерімсіздікке төмен төзімділіктің бірқатар факторлары қалыптасады деген қорытындыға келді. Авторлар сонымен бірге жалпыадамзаттық құндылықтарды, заңдылықты, әлеуметтік белсенділікті және әлеуметтік интеграцияны саналы түсінуге әкелетін әлеуметтік жауапкершілік пен этика категорияларына қызығушылықтың артуын атап өтеді. Экологиялық сананың дамуының жоғары деңгейінде қазақстандықтардың жас буыны экономикалық және саяси дискурстарды қалыптастыра алады, сонымен қатар әртүрлі салалардағы тепе-теңдік пен келісімділік мәселесінде мемлекетке ақыл-ой білдіре алады.

Ұсынылған зерттеу бірнеше бағыттарды бірден қарастырады, сондықтан бұл нәтижелер экологиялық Аискурстың заманауи нысандарының өзгергіштігін, аудиторияның мінезқұлқындағы өзгерістердің ерекшелігін, оны дәстүрлі БАҚ-ты қоспағанда, өзінің мазмұны мен медиа байланысын құруға қабілетті белсенді бағдар, аудитория агентіне айналдыру түсіну жолдарын қызықты етеді.

Түйін сөздер: экология, әлеуметтік желілер, жастар, экологиялық түсінік, тұрақты даму, аудитория.

\section{Е. Аудинова, Ш. Талгат}

Казахский национальный университет им. аль-Фараби, Казахстан, г. Алматы, e-mail: Elena.Dudinova@mail.ru;

e-mail: talgatsholpan@mail.ru

\section{Экологический дискурс в социальных сетях Казахстана: конструкция императива}

Конструктивные изменения медиаландшафта за счет интенсификации социальных сетей способствова^и созданию новых модулей социального Аискурса. Особый интерес сегодня приобретает экологическая тематика, популярность которой обусловлена рядом факторов, в числе которых - рост экологической осведомленности, вызванный открытым Аоступом к информации в социальных сетях, повышение уровня грамотности в вопросах природопользования, сохранения окружающей среды, а также быстрое оповещение об экологических инцидентах.

Цель исследования - проанализировать влияние экологического контента социальных сетей на конструирование экологического императива в сознании молодежи Казахстана. В этой связи были изучены наиболее популярные социальные сети, произведена сегментация аудитории по возрасту и уровню образования, проанализирован контент социальных медиа в сфере экологии. Используя методы сравнения, обзора, контент-анализа и опроса, авторы определили наиболее устойчивые признаки конструирования экологического сознания молодежной аудитории социальных сетей.

Авторы пришли к выводу, что сегодня в сознании молодых казахстанцев все настойчивее проявляется тенАенция вкАюченности экологической тематики в массив концепции устойчивого развития, в итоге формируется ряд факторов низкой терпимости к Аисбалансу в Аанной сфере, вк^ючая политику и экономику. Также авторы отмечают повышение интереса к категориям социальной ответственности и этики, что приводит к осознанному пониманию общечеловеческих ценностей, верховенства закона, социальной активности и стремлению к социальной интеграции. На более высоком уровне развития экологического сознания молодое поколение казахстанцев способно формировать экономический и политический дискурс, а также аккумулировать ментальный призыв к государству в вопросе баланса и согласованности в самых разных сферах.

Представленное исследование предполагает интеграцию сразу нескольких направлений, что делает ее результаты интересными Аля понимания вариативности современных форм экологического дискурса, специфики изменений поведения аудитории, ее преобразования в активного актора, аудиторию-агента, способного к генерации собственного контента и медиакоммуникации, исключающей традиционные медиа.

Кмючевые слова: экология, социальные сети, молодежь, экологическое сознание, устойчивое развитие, аудитория.

\section{Introduction}

Nowadays the level of understanding of environmental issues is built on several platforms. The first is directly environmental. Historically, the topic of environmental disasters and cataclysms has been sensitive for the residents of Kazakhstan, the experience of radiation and chemical pollution, military polygons, virgin land development, large construction projects have caused significant environmental damage to the country's population and ecosystem. Unfortunately, modernity is demonstrated by the increase of environmental risks and the strengthening of dangerous anthropogenic factors. Nowadays Kazakhstan is the state with the highest greenhouse gas emissions in Central Asia. 
According to the Ministry of Ecology, over the past year, 2019, "actual emissions of pollutants into the atmosphere amounted to 2.4 million tons ... According to the forecast, in 2030 actual emissions of pollutants will amount to 3.6 million tons. It means, that they can grow 1.5 times for 10 years ... Currently, over 120 million tons of MSW are accumulated at 3,500 landfills of the country and more than 5 million tons of MSW are generated annually. For comparison, the size is about 42 football fields" (Davydova O. 2020).

The next platform is government participation and regulation. In the field of environmental protection, the Government of Kazakhstan has adopted more than 30 Laws, Codes, Decisions and Rules. In 2007 - the Environmental Code, in 2009 - the Law supporting the use of renewable energy sources, in 2013 - the Concept of transition to a "green economy". It is important that Kazakhstan is actively integrating with the world community for the benefit of development of renewable energy, clean technologies and infrastructure. "Moreover, it promotes international cooperation for sustainable development through the Green Bridge Partnership Program (GBPP)." Within the framework of this program, a complete transition to a green growth model is planned based on the transformation of traditional sectors of the economy and the development of new industries based on renewable energy sources by the year 2050 "(Samruk-Kazyna, 2018). Thus, it must be recognized that the state is taking conceptual steps aimed at a positive solution to environmental problems and the sustainable development of the economy and society.

In April 2020, the Cabinet of Ministers approved and submitted for approval to the Parliament of the Republic of Kazakhstan the Draft of a new Environmental Code. However, the document caused heated discussion and comments in the media. Experts called it repressive, tightening state policy and not motivating for business, and suggested finalizing and postponing the implementation to the post-crisis period (Zakon.kz, 2020). As the Chairman of the Committee on Geological Industry, Mining, Coal Mining and Metallurgy, National Chamber of Entepreneurs Atameken Nikolay Radostovets noted: "Considering the high cost of projects to reduce emissions of harmful substances, the introduction of BAT (Best Available Technology) throughout the world is accompanied by the adoption of economic incentive measures. However, for some reason, Kazakhstan decided to become an exception and use the whip method" (Informburo.kz, 2020).
In this case, it is worrying that the new document, which is extremely important for normalizing the environmental situation in the country, has not been agreed with all stakeholders, has not passed an economic examination, does not stimulate environmental emissions from representatives of the industry business, does not prescribe motivating mechanisms, and leads the role of state only to supervisory functions. This approach postpones the adoption of a new eco-code for an indefinite period and, thus, delays the process of Kazakhstan's transition to a "green economy" and the fulfillment of the obligations of the international agreements it has adopted before.

The next level of problems is based on environmental awareness. Against the background of a fundamental understanding of the importance of environmental thinking and behavior, the principle is laid down in the minds of some citizens: first the economy, then the ecology. Consequently, many environmental problems are resolved on a residual basis. Large companies conduct environmental campaigns or social projects for enhancing their image, but not as part of a environmental strategy. It is clear that capital-intensive injections into environmental programs can afford relatively rich enterprises. And in this context we are not talking about the mining and processing industries, the environmental emissions of which are prescribed by law.

In this area, it is necessary to revise the concept of consumption, the whole system of human life, and minimize the consequences of the anthropological factor on nature. A systematic analysis of the environmental consciousness of Kazakhstanis is needed, which will identify existing barriers and possible solutions, ways of modernization, restructuring the traditional philistine thinking of society. Today, a new sustainable consumption policy is in demand, which has a positive effect on markets and society, contributing to both the effective implementation of technologies and behavioral changes (Schroeder, P., Anantharaman, M. 2017).

The central platform of environmental awareness, which is interesting to the authors of this article, is the mental eco-consciousness of Kazakhstan's youth, which is confidently segmented according to various characteristics: place of residence, age, level of education, income, etc. It is reasonable to assume that the communication sphere of generations $\mathrm{Y}$ and $\mathrm{Z}$ is on the Internet. Social networks sometimes act as the main source of information and the formation of public and individual opinions of a network user. 


\section{Materials and methods}

Considering the current condition of aggravation of contradictions generated by the uneven interaction of mankind with the natural and the environment, socio-economic, natural, political and ideological and other factors, young people are less and less interested in communication in traditional linear formats: information source, media - audience. New types and segments are emerging: streamers (non-professionals reporting from events), commentators (actively using feedback opportunities); bloggers (authors who systematically keep electronic diaries).

The Internet audience actively confirms Stuart Hall's theory of encoding and decoding information (Daniel Chandler, Rod Munday 2011), which described the recipient's independence in decoding and interpreting the sent message. Moreover, the sign of understanding (negative, positive or contractual perception) of the text varied depending on the cultural background, economic situation and personal experience of a person. Thus, there are three forms of behavior arise: the receiver accepts the "preferred" values of the sender; the recipient, relying on the opposition code, denies the message; a "contractual" meaning arises, in which both something of the "preferred" is combined, and its other part is denied.

Thus, the Internet activates a new look at the three components of mass communication:

- the meaning of the message cannot be clearly fixed by the sender

- a message cannot always carry an obvious and clear meaning

- the audience is not a passive receiver of the message.

New communication technologies initiate the emergence of a group of models - the "audience-agent", in which individuals are seen as free agents, independently generating media consumption, interpreting texts, generating their own opinions. And, in this regard, the researchers do not study the impact of media on the audience. But they ask the question: what do people do with the media?

Another observation, the media audience has ceased to be mass, in terms of the similarity of the perception of the information message, there is a differentiated audience, forming individual or group reactions (BermejoFernando2007). Today, it becomes relevant to study information about the online behavior of audience members: their preferences, reviews, clicks, etc.

In the face of the challenges of the 21 st century, social networks are gaining serious momentum. The number of users is increasing, and thus, the dissemination of information through social networks is becoming a convenient tool for influencers (people who can influence their audience). In this aspect, there are both certain difficulties and many advantages.

In general, the concept of "social network" was introduced by the sociologist James Barnes in 1954 (Melnikova M.S., Yakovlev I.P. 2014). At that time, this concept had no connection with the Internet. According to Barnes, a "social network" is a social structure consisting of a group of nodes. And these nodes are represented as social authors and the connections between them.

Nowadays social networks are not just a tool of obtaining information. These are numerous communications and connections between different sources and recipients, existing and potential stakeholders. Social networks are also technologically developed and a tool of communication continuing to increase. It is important that this area can be created, developed and moderated by users themselves. Social networks are also able to build relationships between people, providing the implementation of many tasks: business, leisure, entertainment, receiving data in a variety of forms: images, videos or texts that are developed and shared by users (Kaplan \& Haenlein, 2010; Kietzmann, Hermkens, McCarthy \& Silvestre, 2011).

Social networks occupy the important place in the lives of young generation of Kazakhstan. Users come in approximately equal numbers, both from a computer and from mobile devices. According to statistics, the youth of Kazakhstan spends several hours on social networks daily. In the near future, this figure will grow even more.

Popular social networks among young Kazakhstanis are Instagram, VK and Youtube (regardless of the city). The greatest interest is concentrated in the Vkontakte network (71\%). And it is especially popular among the younger age group (1518 years). In second place is Instagram (59\%). It is also more popular with schoolchildren and students. Facebook is not particularly popular among young people in Kazakhstan $(10 \%)$ (especially among the younger age group - 7\%) (BRIF Research Group).

This can be schematically represented in Figure 1. 


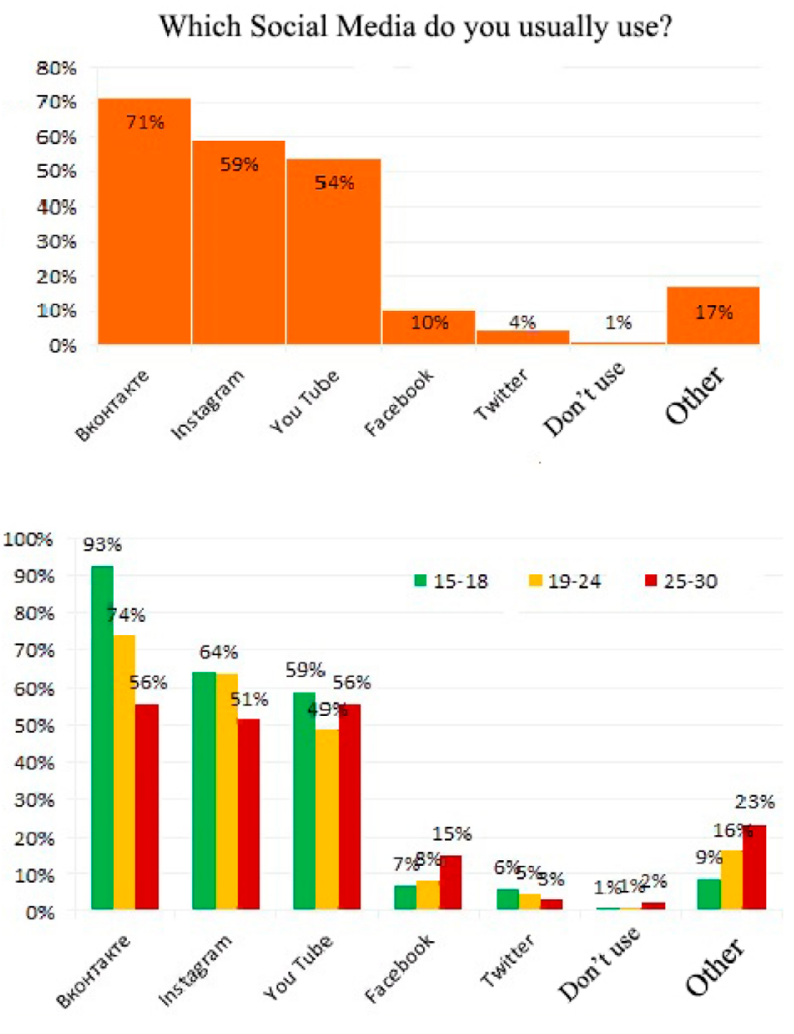

Figure 1 - (BRIF Research Group)

It is noted that social media is still an excellent platform for brand advertising. So, $74 \%$ of users rely on social networks when they decide to buy a product. At the same time, buyers no longer trust many large influencers in social media. $61 \%$ of users trust the recommendations of relatives more than celebrities. It is noteworthy that of all social networks, micro-influencers prefer Instagram. These conclusions were made by SocialPubli, which interviewed 2667 bloggers with less than 10 thousand subscribers from Europe, North and South America. Key findings: $76 \%$ of micro-influencers called Instagram their favorite social network for working with brands. $10 \%$ of respondents preferred Twitter, 9\% chose Facebook. Micro-influencers called stories in Instagram the most attractive format for collaboration with brands in the next 6-12 month. In second place are Instagram posts, in third is IGTV (Inbusiness, 2020).

In 2019, Twitter banned the publication of political news. Other social networks may well follow his example. The increased need for regulation and fact-checking will reduce the amount of fake news on social media.

For example, the BRIF ResearchGroup team conducted a large-scale study of trends among the youth of Kazakhstan. A quantitative survey was conducted in 7 major cities of Kazakhstan (627 respondents), and a large qualitative study, including 15 focus groups and more than 10 in-depth interviews with key trendsetters and experts. All this was supplemented by statistics in the framework of DeskResearch. One of the important trends realized in the youth environment of Kazakhstan is the total digitalization and the growing popularity of social networks.

\section{Literature review}

Foreign and domestic researchers are quite actively studying the problems of social networks, their impact on language and public morality. There are also interesting studies directly on the environmental content of social media.

In particular, they note the possibility of social networks to increase environmental awareness, create social incentives, attract financial donations, and increase personal participation of citizens in social activities (Mattila \& Hanks, 2012). Some researchers include the concept of sustainability in the social responsibility module (Boulouta $\&$ Pitelis, 2014). Scientists at the Cambridge Press Institute (Wasserman \& Faust, 2007) write about the activity 
of users who can create community generations, produce original content and, more importantly, make it accessible to as many people as possible through interaction on various social networking platforms.

A group of scientists from Europe and the United States indicates a decrease in environmental and social activities of representatives of Generation Y and suggest, in this regard, to connect the resources of the government and educational institutions to stimulate interest in socio-environmental issues (Schroeder, P., Anantharaman, M. 2017).

Canadian scientists also note that through social networks, the audience gets access to platforms for organizing dialogs, discussions of environmental topics. Thus, digital formats create and stimulate communication (Ghali, M. R., Frayret, J. M., \& Robert, J. M. 2016).

Iranian authors from the University of Tehran in their study noticed that social media quickly became an important marketing and communication tool for private, public and non-governmental organizations around the world to facilitate their organizational presentation, daily events and publications. Scientists also note that such a simple but effective action can lead to quick awareness of environmental incidents and timely response from various organizations and authorities responsible for the environment (RoshandelA.T., LabafiS., RobatiM. 2016).

Researchers from Malaysia have highlighted the importance of higher education in the establishment and development of environmental awareness. Higher education, according to scientists, holds the responsibility for the formation of environmental awareness among students and staff around the world and the change in the attitude of future generations to the importance of preserving the environment. Universities have good potential for teaching the younger generation. Scientists argue that social media can be used as a tool to inform students about the environmental situation, as well as their education and green upbringing (Hamid S., Sulaiman H., Norman A.A. 2016).

An interesting study was conducted by scientists of the Kazakhstan Research Center "Molodezh" in 2017. The indicators of youth's social activity were analyzed: the value of the worth of active life in the minds of youth, the level of youth's activity on the Internet, the level and motivation of youth membership in youth organizations, the attitude of youth to volunteering and the motivation to participate in it, and many other aspects. The results of the study allow us to investigate the attitudes and values of modern Kazakhstani youth (Kaldybaeva O.V. et al., 2018).

\section{Results and discussion}

The topic of ecology certainly excites young people, this can be seen in the activity of users and the content of social networks. This is evidenced by multiple posts that find a wide response from a similar audience. A youth environmental movement is widely deployed in Kazakhstan, it is especially actively supported in large cities: the Youth Public Association Earth Fund "Sustainable Development", "Akbota Public Fund", "Kazakhstan Volunteers Alliance", "Organization of the Scout Movement of Kazakhstan", "Orleu-Consulting", "Incubator of sustainable development projects" and others.

Such involvement of young people in social activities indicates a caring attitude towards the future of the country. Through an environmental theme, civil society is awakening, which is protesting, and this is the first time in 29 years of independence. Now the government has even allocated venues for rallies, although the first protests were accompanied by arrests and detentions. Youth movements and groups are created and operate (Oyan kazak!, Zhaz Otan, "For the Future of Kazakhstan" and others).

Social networks, being a generally accessible, operational and convenient platform for receiving information, exchanging opinions, forming communities of interest and political views, are becoming just the platform on which young people actively communicate. Today, every Kazakhstani has at least three services. There is also a choice: Instagram, FB, VKontakte, WhatsApp messengers, Telegram, etc.

With the development of social networks, government bodies, officials of various levels are forced to restructure their communication policies with the public, engage in dialogue with the public, create websites, social media accounts, and communicate with the public without intermediaries. In September 2019, President of the Republic of Kazakhstan K. Tokayev addressed the people his message "Constructive public dialogue - the basis of stability and prosperity of Kazakhstan", in which he substantiated the concept of "the Hearing State", which quickly and effectively responds to all constructive requests of citizens. "Only through a constant dialogue of power and society can a harmonious state be built in the context of modern geopolitics," the President believes (K. Tokaev, 2019). 
These are, of course, completely new processes launched in Kazakhstan, including active social communications. And also due to the transparency of many political processes due to the Internet. As part of this study, the authors analyzed a significant amount of data to show how social networks evoke the environmental awareness of youth.

The content and content of the five most wellknown Instagram pages on environmental topics that have an impact on their audience were studied, some of them even receive support from the media.

Table 1 - A description of these pages

\begin{tabular}{|c|c|c|}
\hline Instagram page & Subscribers, activity, about the page & Target audience \\
\hline @ Recycle.birge & $\begin{array}{l}4000 \text { - number of subscribers } \\
\text { Close cooperation with the media, collaboration with foreign experts, } \\
\text { the results are recorded in the form of a personal blog and they } \\
\text { provide free access to all collected materials. }\end{array}$ & $\begin{array}{l}\text { Almaty to a greater extent. } \\
\text { Kazakhstan }\end{array}$ \\
\hline $\begin{array}{l}@ \text { Kazakhstan_waste } \\
\text { recycling_kwr }\end{array}$ & $\begin{array}{l}13400 \\
\text { Promoting personal blog }\end{array}$ & Almaty \\
\hline (a)Chisto.men & $\begin{array}{l}18700 \\
\text { Non-standard presentation of information, photographic protocol of } \\
\text { environmental actions, humor. } \\
\text { Due to this, information quickly spreads across a Russian-speaking } \\
\text { audience, and these are CIS countries. Information about this account } \\
\text { is transmitted through reposts in instagram stories. The average user } \\
\text { has an average of } 200-300 \text { views (a survey of the inner circle of the } \\
\text { authors) }\end{array}$ & $\begin{array}{l}\text { Russia, Kazakhstan, and other } \\
\text { CIS countries } \\
\text { Analysis of likes and } \\
\text { comments makes it clear that } \\
\text { the approximate age of the } \\
\text { audience is } 20-35 \text { years. }\end{array}$ \\
\hline @rocketplastic & $\begin{array}{l}6614 \\
\text { Promotion of plastic recycling. This project has an active work } \\
\text { with the media of Kazakhstan, in particular with the youth online } \\
\text { publications TheSteppe, WoxPopuli, TheVillage }\end{array}$ & $\begin{array}{l}\text { Almaty } 80 \% \text {, Other regions of } \\
\text { Kazakhstan } 20 \%\end{array}$ \\
\hline @ varyavalovil & $\begin{array}{l}142,000 \\
\text { A popular Russian eco-blogger with the education of a journalist. } \\
\text { It differs in that it carefully checks the accuracy of the published } \\
\text { facts. Bloggers distributes information about her blog through } \\
\text { advertisements and other bloggers and through targeted advertising } \\
\text { (distribution of advertising: CIS countries) }\end{array}$ & $\begin{array}{l}\text { Russia, CIS countries. } \\
\text { Mostly Kazakhstan, Belarus, } \\
\text { Ukraine }\end{array}$ \\
\hline
\end{tabular}

Instagram page @ Recycle.birge provided data about its audience. These data can be seen in Figure 2.
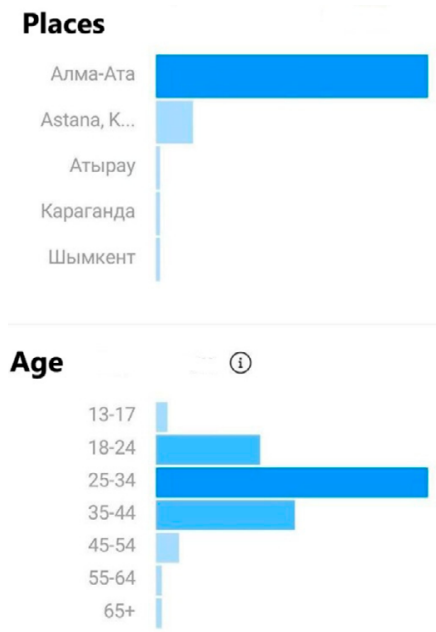

Figure 2 
We see that in fact on this page are subscribed, to a greater extent, users from 18 to 44 years old. However, an analysis of the activity in the comments and likes showed that users are involved here in the age range between 18-34. That is, these are the people who leave comments, participate in discussions and send reactions. Also, the specifics of this age group is a more confident use of tools of social networks, as well as the use of all possible trends that appear on average every six months.

Environmental awareness is shown by the following factors: reposts on Instagram stories of the most interesting posts on environmental topics. As shown in table 1, each average user has an average of 200-300 views. That is, environmentally aware young people are not only ready for activities themselves, but also encourage others to think about important environmental issues. This is a feature of social networks.

Some of the described Instagram pages have a number of subscribers from 4,000 to 18,000 thousand. By the standards of this platform, this is not such a large number. However, if we take, for example,@Recycle.birge,@rocketplastic, then these pages, having a minimum number of subscribers, but they have media support. Environmental project@rocketplastic - has a highest number of media collaborations. An important point: among the supporting media there are Kazakhstani youth online publications The Steppe, Wox Populi, The Village. Thus, with the help of social networks, many environmental projects are able to attract attention from the media, and most importantly, from the population, in particular young people.

According to researchers, Kazakhstani youth are getting the basics of environmental knowledge from school. Since the 90s of the XX century, in all higher and secondary special educational institutions, compulsory teaching of the basis of environmental knowledge has been introduced with the aim of forming an environmental culture of the individual. The basic programs were adopted: "The National Strategy of Environmental Education and Training in the Republic of Kazakhstan" (1998), "The Program of Environmental Education" (1999), "The Concept of Environmental Safety of the Republic of Kazakhstan 2004-2015." (2003) and others. At the state level, the Concept of Environmental Education was adopted, developed jointly by the Ministry of Education and Science and the Ministry of Natural Resources and Environmental Protection, which defines the goals, objectives and main areas of activity for the development and implementation of environmentally significant national educational projects (Concept, 2005). Since 2011, the discipline "Ecology and Sustainable Development" (Nurgabylova A.Sh., 2018) has been taught as mandatory discipline in universities and colleges.

Thus, environmental knowledge naturally enters the educational thesaurus of Kazakhstani youth. Further interest in this topic, according to studies, is also dictated by a number of factors:

- the development of social networks as the basis for replenishing knowledge about the world, information on eco-communities, and social activity in the field of environmental protection;

- Kazakhstan's active participation in UN projects, inclusion in a number of international initiatives, government environmental programs;

- the growing fashion on environmental topics cannot be denied: green cosmetics, eco-products, social marketing. "The paper box from the burger is made from recycled materials. A glass with a milkshake has become thinner. The oil on which the food was cooked is not discarded, but stored in a special container. It is mixed with diesel fuel and biofuel is produced for the company's trucks ... Just replacing a plastic salad bowl with a paper one saves 1,900 tons of materials from non-renewable resources. And 300 million wooden sticks for stirring coffee make eight ten-ton plastic trucks unnecessary. A holder that does not allow a client to grab more than one napkin at a time will save thousands of tons of timber" (Danchenok L.A., 2003). Such social projects launched by well-known brands undoubtedly not only attract consumers, but also attract young people with eco-ideas.

- viral photos and videos on social networks with fragments of environmental pollution, water and air spaces.

From time to time, text and visual materials are published on social networks demonstrating the facts of animal abuse, the destruction of rare species of flora and fauna, and environmental pollution. Of course, young people, as active and part of the audience, are actively responding to such publications. This is evidenced by reposts to the story on instagram, as well as, in some cases, comments on this subject.

An interesting case is the story of the struggle of eco-activists to preserve the Kok Zhailau tract located on the territory of the Ile-Alatau State Nature Reserve. In 2002, the idea of building a resort ski resort "Kok-Zhailau" has established. Thousands of people advocated for the conservation of the unique nature of the national park, and the public campaign "Defend Kok-Zhailau!" began. In 2012, the Green Salvation environmental society collected signa- 
tures against construction. Hot debates took place in 2013, 2014, 2017 (Sputnik, 2018).

Each time the media wrote about Kok-Zhailau, violent reactions followed on social networks. Young people shared their emotions on Instagram, and the more adult population of 35+ on Facebook. Thus, massive unrest passed in 2019. Users actively disseminated information about the desire to stop the progress of the project for the construction of a ski resort. As a result, under pressure from the public, in November 2019, by decree of President Kassym-Zhomart Tokayev, it was decided to ban the implementation of the project (Forbes, 2019).

In neighboring Russia there is also an interesting example of social activity. The story of Lake Baikal provoked an active reaction not only from Russian but also from Kazakhstani youth. According to some reports, the Russian authorities sold the right to build a plant to Chinese business. Citizens created a petition, collected more than a million signatures, with the help of social networks and a special hashtag they managed to achieve tremendous results: the construction of the plant is prohibited by the court.

Environmental topics are gaining momentum around the world. That's possible to say this is such a peculiar and useful hype. The great excitement that occurred around the young environmental activist Greta Tunberg in September 2019 increased interest in environmental issues.

\section{Conclusion}

New technologies, social networks and their further development represent a multi-level base for study. Social activity does not come from technology, but is realized with their help, gaining the quality of new communication. The widespread adoption of multi-platform initiatives is transforming the modern media landscape. Young people today are determined to receive information from various sources to form their opinion, relying on a complex system of comparisons of information modules.

Today we can talk about a structural phenomenon - the alignment of activity metrics in the social networks of young people in developed and developing countries. Social networks initiate processes of activity, form a civic position, reduce the distance of power. By analogy with word of mouth, which is trusted more, social networks increase audience coverage with lightning speed. And usually it is not predictable. In the framework of this study, the authors also came to the conclusion that social networks are one of the most effective tools for supporting and promoting environmental ideas among young people. In the future, you can explore the possibilities of social networks to create conditions for the effective promotion of environmental projects, as well as the development of environmental education and awareness among young people and the younger generation.

In the environmental discourse of social networks, diversification is taking place: separate pages are being created for cleaning or sorting garbage, supporting the environment, personal pages of ecobloggers are being developed that promote "green ideas". However, the basic forms of regulation of environmental processes, environmental protection, as well as the sphere of environmental education remain with the state.

\section{References}

Bermejo Fernando (2007). The Internet audience: constitution and measuremen. New York: Lang, 2007.

Boulouta, I., \& Pitelis, C.N. (2014). Who Needs CSR? The Impact of Corporate Social Responsibility on National Competitiveness. Journal of Business Ethics, 119, 349-364.

Davy`dova O. (2020). Novy`j E`kokodeks. Gazeta Liter. [New EcoCode] 5.02.20. https://liter.kz/novyj-ekokodeks/

Daniel Chandler, Rod Munday (2011), A Dictionary of Media and Communication, Oxford University Press.

https://www.oxfordreference.com/view/10.1093/acref/9780199568758.001.0001/acref-9780199568758

Danchenok L.A. Osnovy` marketinga: Uchebnoe posobie / Moskovskij gosudarstvenny`j universitet e`konomiki, statistiki i informatiki. - M., 2003. - 262 s. [Bases of Marketing: Study Book] Moscow State university of Economics, Statistics and Computer Science. - M., 2003. $-262 \mathrm{p}$

Ghali, M.R., Frayret, J.M., \& Robert, J.M. (2016). Green social networking: concept and potential applications to initiate industrial synergies. Journal of Cleaner Production.

Informburo.kz, (2020). Kak zabotyas' ob ekologii mozhno navredit' ekonomike. [How caring for the environment can harm the economy], April 15th 2020.https://informburo.kz/special/kak-zabotyas-ob-ekologii-mozhno-navredit-ekonomike.html

Samruk-Kazy’na, (2018). Zelenaya e`konomika: realii i perspektivy` v Kazaxstane. [Green economics: reality and perspectives in Kazakhstan]. https://www.sk.kz/upload/iblock/3f5/3f5f8e2087688517bcc667eeebc82630.pdf

Schroeder, P., Anantharaman, M. (2017). Lifestyle Leapfrogging” in Emerging Economies: Enabling Systemic Shifts to Sustainable Consumption. Consum Policy 40, 3-23 (2017). https://doi.org/10.1007/s10603-016-9339-3 
Zakon.kz, (2020). Novy `j E`kologicheskij kodeks v bor`be za e k kologiyu sposoben negativno povliyat’ kak na e konomiku Kazaxstana... 29 aprelya, 2020 [The new Environmental Code in the fight for the environment can negatively affect both the economy of Kazakhsta...] 29th of April, 2020 https://www.zakon.kz/5019781-kak-novyy-ekokodeks-mozhet-otrazitsya.html.

Korporativny`j blog issledovatel'skoj kompanii BRIF Research Group [BRIF Research Group Corporate Blog]https://www. brif.kz/blog/?p=3304

Inbusiness (2020). Kakimi budut social `ny`e media v 2020 godu. [What will social media be in 2020?].kz https://inbusiness.kz/ $\mathrm{ru} /$ news/kakimi-budut-socialnye-media-v-2020-godu

Mattila, A. S., \& Hanks, L. (2012). Antecedents to participation in corporate social responsibility programs. Journal of Service Management, 23(5), 664-676.

Kochergin I.G. (2013) Razvitie social 'ny’x setej e`kologicheskoj napravlennosti. [The development of environmental-friendly social networks].

Mel’nikova M.S., Yakovlev I.P. (2014) Ponyatie «Social'naya set`»v sociologicheskix teoriyax i internet-praktikax. [The concept of "Social Network" in sociological theories and Internet practices]. Bulletin of St. Petersburg State University. Series 9. Issue1. https://www.ecotalk.ru/phorum.html

Greta Tunberg. Electronic resource. Wikipedia - free encyclopedia.

Kaplan, A. M., \& Haenlein, M. (2010). Users of the world, unite! The challenges and opportunities of Social Media. Business Horizons, 53(1), 59-68. Kietzmann, J. H., Hermkens, K., McCarthy, I. P., \& Silvestre, B. S.

Kaldy`baeva O.V., Musataeva F.M., Okasova G.E. Ustanovki molodezhi sovremennogo Kazaxstana na proyavlenie social'noj aktivnosti. [Youth attitudes of modern Kazakhstan on the manifestation of social activity]https://www.elibrary.ru/item. asp?id=36349730

Koncepciya e`kologicheskogo obrazovaniya Respubliki Kazaxstan // E`kologicheskoe obrazovanie v Kazaxstane. - 2005. №1. -S. 3-6. [The concept of environmental education of the Republic of Kazakhstan] // Environmental education in Kazakhstan. - 2005. - No. 1. -WITH. 3-6

Nurgaby`lova A.Sh. (2018). Osobennosti e`kologicheskogo obrazovaniya molodezhi v respublike Kazaxstan. 2018 № 1 (213). [Features of environmental education of youth in the Republic of Kazakhstan]. Bulletin of Orenburg State University 2018 No. 1 (213).

Tokaev K. Konstruktivny`j obshhestvenny’j dialog - osnova stabil nosti i proczvetaniya Kazaxstana. [Constructive public dialogue - the basis of stability and prosperity of Kazakhstan] / President K. Tokayev's message to the people of Kazakhstan / September 2, 2019

Sputnik - informacionny’j portal (2018). Bol’shaya strojka v gorax Almaty'? Stanet li urochishhe "Kok Zhajlyau” kurortom. (2018). [A large construction site in the mountains of Almaty? Will the Kok Zhailau tract become a resort. (2018).] https:// ru.sputniknews.kz/society/20181104/7903445/almaty-kok-zhajlyau-slushaniya.html

Forbes - informacionny`j portal (2019). Reshenie prezidenta RK zapretit` realizaciyu proekta Kok-Zhajlau podderzhali v OON. [The decision of the President of Kazakhstan to ban the implementation of the Kok-Zhailau project was supported by the UN]. https://forbes.kz//news/2019/11/10/newsid_212337?

Wasserman, S., \& Faust, K. (2007). Social network analysis: methods and applications. Cambridge, Cambridge University Press.

Roshandel Arbatani, T., Labafi, S., Robati, M. (2016). Effects of Social Media on the Environmental Protection Behaviour of the Public (Case Study: Protecting Zayandeh-Rood River Environment). Int. J. Environ. Res., 10(2):237-244, Spring 2016

Hamid, S., Sulaiman, H., Norman, A.A. (2016) Social media for environmental sustainability awareness in higher education. International Journal of Sustainability in Higher Education Vol. 18 No. 4, 2017 pp. 474-491 C Emerald Publishing Limited 1467-6370 